\title{
The Ethiopian Coup d'Etat of December 1960
}

\author{
by GHRISTOPHER GLAPHAM*
}

By contrast with many other African states, the Ethiopian Government has in recent decades been almost monotonously stable. The Emperor Haile Selassie reigns and rules through a political system which remains in essentials the direct descendant of the imperial Government as it has existed down the centuries. ${ }^{1}$ In the last quarter-century, only the attempted coup d'état of December I96o has seriously challenged his régime. The purpose of this article is to disentangle the various elements present in the coup, in order to illuminate the themes of rebellion and attempted revolution in an indigenous African polity.

\section{A BRIEF OUTLINE OF EVENTS ${ }^{2}$}

On Tuesday, I3 December 1960, Haile Selassie was away on a state visit to Brazil. That night the Commander of the Imperial Bodyguard, Brigadier General Mangestu Neway, ${ }^{3}$ took control of the imperial palace in Addis Ababa; he there detained the Emperor's eldest son, Crown Prince Asfa-Wasan, and leading politicians, including the Ministers of Commerce, Defence, and the Interior. He was aided by his younger brother Germamé Neway, a radical subprovincial governor who was mainly responsible for the planning and political motivation behind the coup, and the two brothers were joined by the Chief of Security, Colonel Warqenah Gabayahu, the Police Commissioner, Brigadier General

* Research Fellow, Department of Government, University of Manchester; formerly Lecturer in the Faculty of Law, Haile Sellassie I University, Addis Ababa.

1 I have recently examined this political system in my Haile Selassie's Government (London, 1968), and have therefore felt it unnecessary to burden this account with background information.

2 The most detailed account of the coup is in Richard Greenfield, Elhiopia: a new political history (London and New York, 1965), pp. 337-452, from which much of this outline is derived. My own emphases and conclusions often differ from Greenfield's, but I am happy to acknowledge the value of his work in collecting and making available much information which would otherwise be lost. Shorter assessments appear in Robert L. Hess, 'Ethiopia', in Gwendolen M. Carter (ed.), National Unity and Regionalism in Eight African States (Ithaca, I966), pp. 506-II ; and in D. N. Levine, 'Haile Selassie's Ethiopia: myth or reality', in Africa Today (Washington), May I961.

3 Names are given in full at the first mention, and the abbreviated form used in later references is italicised-this is the given name, the second name being a patronymic. 
Tsegé Dibu, and a few educated radicals; they were supported by most of the Imperial Bodyguard.

On Wednesday morning, 14 December, the rebels secured control of most of Addis Ababa and drafted a proclamation, broadcast by AsfaWasan, who is generally regarded as having acted under duress. This attacked Ethiopia's economic backwardness in relation to other African countries, announced the formation of a new government under Asfa-Wasan, and promised the start of a new era. ${ }^{1}$ It helped to secure the support of the university students, who demonstrated in Addis Ababa in the new government's favour.

But the rebels had failed to neutralise a very important group of opponents, who were headed by an influential nobleman, Dajazmach Asrata Kasa, and by the Chief of Staff, Major General Mared Mangasha. These made for the headquarters of the army, on the opposite side of Addis Ababa from the palace and the headquarters of the Imperial Bodyguard. The army and the Bodyguard were two entirely separate military formations, which Haile Selassie kept apart in rivalry to one another; when the guard went against him, a countervailing military force was therefore immediately available in his support.

There followed an uneasy 24 hours. During this period Mangestu and the rebels issued an I I-point programme of proposed reforms, and appointed as Prime Minister a liberal old nobleman and cousin of the Emperor, Ras (Prince) Imru, with Major General Mulugéta Buli, who was popular in the army, as Chief of Staff. Asrata, Mared, and the loyalists spent their time more usefully; they secured the support of the tank squadron and the air force, both stationed within reach of Addis Ababa, and made up their initial shortage of troops by airlifting about $\mathrm{I}$,ooo loyal soldiers in from outlying provinces; they also issued leaflets signed by the Patriarch of the Ethiopian Church, condemning the rebels as anti-religious traitors and calling for loyalty to Haile Selassie. These seem to have had a great effect on waverers and townspeople.

Fighting broke out in the afternoon of Thursday, 15 December. The rebels were heavily outgunned, and were slowly driven back through Addis Ababa on Thursday and Friday. Many ordinary Bodyguard soldiers lost heart on discovering they were fighting against the Emperor, as they had been given to understand that they were fighting for him; the townspeople, once the fighting started, gave fierce support to the loyalists. Before retreating, Germamé and others turned machine-guns on the politicians who had been rounded up on the first night and since

1 This proclamation is published in Greenfield, Ethiopia, pp. 398-9, with several other broadcasts and documents connected with the coup. 
kept as hostages, killing ${ }_{5} 5$ of them. Later Germamé and Warqenah committed suicide; Tsegé was killed in action; Mangestu was captured, and was tried, condemned to death, and hanged the following March.

Haile Selassie flew first to Asmara, which, like all the provincial centres, had remained loyal to him; on Saturday, i 7 December, he re-entered Addis Ababa amidst fervent rejoicing, and the attempted coup d'état was all but over. Official casualty figures, which are likely to be underestimates, indicate at least zoo killed, many of them civilians caught in the street fighting. ${ }^{1}$

\section{INTERPRETATIONS OF THE GOUP}

So here we are considering a single short and violent attempt to overthrow the Ethiopian Government, which lasted only four days and took place some eight years ago. What is its importance? What questions do we need to ask about it?

For one thing, the coup illuminates the power bases of the imperial régime, which are latent except in crisis, including the nobility, the Ghurch, and the armed forces; it therefore helps us to understand the Government which it tried to overthrow. For another, it has had a considerable effect on the later growth of political consciousness in Ethiopia, both in the armed forces and among the intelligentsia of Addis Ababa; in this respect it may cast a shadow on future events. But my aim here is to look at the coup itself, and in particular to examine the claim that it was very much more than the palace plot which it might appear at first sight to have been. Two quotations illustrate this claim:

There have been coups, revolutions and political assassinations throughout Ethiopia's long history but the abortive Revolution of 1960 was different in one vital respect. Its leaders sought not merely to displace the then national leaders, but to reform and remould the whole system of government. It may be said that in December 196o Africa's 'wind of change' reached even the remoteness of the Ethiopian High Plateau. ${ }^{2}$

In the confusion that followed there took place the first real attempt at revolution in Ethiopian history. Hitherto there had been a number of court intrigues, palace coups... and regional disturbances... The purpose of the leaders of the coup was different, however, and marks a major turning point in modern Ethiopian history. ${ }^{3}$

1 The Ethiopian Herald (Addis Ababa), 21 December 1960 and 9 March 1961, gave two completely inconsistent sets of figures; the East African Standard (Nairobi), 20 December 1960, estimated about 2,00o dead and wounded.

2 Greenfield, Ethiopia, p. 2.

3 Hess, 'Ethiopia', in National Unity and Regionalism, p. $5^{\circ 6 .}$ 
These quotations both imply a distinction between what may be called 'rebellions', which seek only to change the individuals in power within an accepted framework, and 'revolutions', which try to substitute a whole new form of government. This distinction has been formulated by Gluckman and others, ${ }^{1}$ and is central to the significance of the I 96o Ethiopian coup. I shall therefore try to apply it to this event-to its leadership and organisation, the appeals which the rebels made, and the sources of support open to them and their opponents-so as to show in what ways it belonged to the existing political tradition, and in what ways it was a new departure.

As the quotations suggest, attempts to oust the Emperor by force are by no means unusual in Ethiopia. Haile Selassie himself rose to power by a palace coup in 1916 , and he in turn has had to guard against similar attempts on his own position; abortive plots, none of which got nearly so far as the 196o one, were uncovered in 1943, 1947, 1951, and I961. They are a recognised way of disposing of Emperors who are either too weak to be effective, or who do not abide by essential conventions of the Ethiopian state system. Although such plots fail far more often than they succeed, it is hardly too much to say that an Ethiopian Emperor is subject to the rule of the survival of the fittest.

\section{LEADERSHIP AND ORGANISATION}

The leadership of the 1960 revolt provides one possible source of innovation. This falls broadly into three groups. First, there was the Commander of the Imperial Bodyguard, with the officers and men who helped, followed, and obeyed him; they formed the indispensable power base without which the attempt could never have got off the ground. Secondly, there were a few security officials, including the police chief, the security chief, and the Emperor's personal guard, who joined the attempt but did not bring their own organisations into it; one section of the police force, indeed, took a key part in opposing the rebels. Thirdly, there were the intellectual radicals.

Now, at least as far as the first two categories are concerned, this was very much an inside movement, from men who were close to the centre of the existing palace Government. Mangestu and Germamé were members of a well-established Shoan noble clan called Moja, which had supplied a steady succession of soldiers and governors for the past century, but which had lately been rather out of favour; the method of

1 See, for example, M. Gluckman, Order and Rebellion in Tribal Africa (London, 1963), p. 12. 
the Praetorian Guard was the classic one for their purpose. The police and security leaders, though self-made men, had similarly a central place as the Emperor's trusted protégés. Here, anyhow, it followed the standard pattern of the palace putsch.

Among the intellectuals-men with a university degree, most of them educated abroad-the outstanding leader was Germamé. The coup's claims to the status of an abortive revolution depend very largely on the position accorded to this one individual. He had been educated in the United States, where he wrote a short dissertation on settler land policies in Kenya, which he understandably detested, and where he showed some awareness of events in other African countries. He returned to Ethiopia in 1954, and his experiences as a reforming but thwarted subprovincial governor seem to have led him to persuade his brother to launch the coup. He appears to have been an arrogant and ruthless character-it was he, rather than the soldiers, who led the massacre of hostages-but we have very little knowledge of his views and intentions beyond his fervent belief in the value of economic development. He did not expound them during the revolt, and his opinions as a student are at best an unsatisfactory substitute. ${ }^{1}$

After Germamé's death, the Government claimed, among other things, that he had intended to assassinate all ministers, judges, governors, officers, traditional leaders, and soldiers over $40 ;^{2}$ but such views were produced only to discredit him, and this astonishing butcher's order would have included both himself and his brother. Claims that he wanted to nationalise all land and disestablish the Orthodox Church sound rather more likely; but an impartial assessment is practically impossible, since both those who hail him as a revolutionary hero and those who vilify him as a bogey-man have been concerned to present him, for their different purposes, in as radical a light as possible. We have no adequate answer to the basic question, What changes did he think necessary in the existing system of government?

The most striking facts about the other educated rebel leaders are, first, that there were very few of them, and, second, that they were all closely related to people already in the plot. At this time, there were between 150 and 200 graduates of the post-war generation in middlelevel government posts; ${ }^{3}$ with graduates from the local university, and others who had recently returned from abroad or taken up non-

1 These opinions are examined in Greenfield, Ethiopia, pp. 339-5I.

2 Hess, 'Ethiopia', in National Unity and Regionalism, p. 509.

3 This figure has been inferred from Administrative Directory of the Imperial Ethiopian Government (Addis Ababa) for July r 959 . 
governmental posts, there was a total graduate élite of roughly $400-500$. Yet, of all these, only four were definitely committed to the coup: ${ }^{1}$ Germamé himself, two of his cousins, and the brother of an officer in the Bodyguard. It has been suggested, probably correctly, that other intellectuals supported the coup and took a part in planning it; ${ }^{2}$ but, if so, they did not publicly identify themselves with it when it broke out, and backed away quietly when it looked like failing. Very few, if any, Ethiopian graduates came out for the coup who had not been in the secret beforehand, though certainly many wavered until they could be sure which side would win. Despite its reforming aims, it cannot therefore be classed as a revolt by any class or élite of younger graduates against an older and more conservative régime.

This generalisation excludes the contemporary generation of students, who came out enthusiastically in favour of the new régime. It is doubtful, however, if they had any very clear idea of what they were about, beyond a dislike of the existing Government and a very generalised desire for progress. They declared that the new government would provide ' freedom of speech, press and political parties', ${ }^{3}$ aims which the coup leaders themselves did not mention and which they were unlikely to have granted. The difficulties of a very confused situation are suggested by a report that one student leader 'clarified his position by saying that he is in favour of the new régime provided that it is not a military coup d'état' . ${ }^{4}$

It did not escape the notice of Ethiopian observers that four of the rebel leaders (Mangestu, Germamé, and their two cousins) belonged to the Moja clan, which had something of a reformist tradition and some grounds for dissatisfaction, and this has led to suggestions that the revolt could be explained in terms of internal lineage politics. But this is at best an over-simplification, in that some Mojas remained loyal to the Emperor, while several non-Mojas were actively involved; and there has been no evidence that Mangestu and Germamé took the lead because of their Moja ancestry. The importance of these relationships lies partly in that educated Ethiopians did not stand by the coup unless they had some personal, family reason for doing so, partly in that the principal leaders were noblemen. This does not mean that they were conservative, but it does mean that they had inherited a certain authority, and a certain confidence in their ability to lead, which is generally lacking in non-noble politicians. Their role is not a coinci-

1 See The Ethiopian Herald, 2 I December 196o, which contains the most comprehensive official list of ringleaders.

2 Greenfield, Ethiopia, pp. 379 and 420.

3 Hess, 'Ethiopia' in National Unity and Regionalism, p. 507.

4 News and Views (published by the students of the University College of Addis Ababa), 16 December 1960 . 
dence, for almost every plot or revolt against Haile Selassie in the last $5^{0}$ years, whether conservative or reforming, has been led by noblemen or else by resistance heroes with analogous sources of authority; noblemen have also tended to be the most independently minded ministers within the Government.

The restricted nature of the leadership also reflects great difficulties of organisation. Ethiopia has no political parties, and other channels through which opposition can be organised are virtually absent. The traditional Ethiopian reserve and distrust of outsiders, strengthened by the presence throughout the administration of informers eager to report disloyalty, add to the difficulties of plotting; and in these circumstances, the members of one's family are often the only people whom one can trust. There are varied opinions as to how much planning went into the coup; Greenfield reports the existence of a 25 -man 'Council of the Revolution', with an understandably shadowy membership, but by his own account this seems to have been more of a hindrance than a help to the efficient prosecution of the plot. ${ }^{1}$ Others suggest that the whole affair was launched at very short notice, in order to take advantage of Bodyguard discontents over officers' pay.

There is general agreement that the actual date was fixed only a few days in advance, to avoid the danger of the secret getting out. The rebels then went ahead, without organisational support outside the Imperial Bodyguard, on the assumption that, once they had struck the first blow, others would join in. This assumption was not realised and, after the successful seizure of Addis Ababa on the Wednesday morning, the initiative gradually slipped to the loyalists. The organisation of the coup thus does not reveal any new movement of a 'revolutionary' kind, and the loyalties involved remained those appropriate to Ethiopian palace government.

\section{THE AIMS OF THE COUP}

But, while the immediate circumstances of the coup, and its immediate failure, can be explained by its restricted leadership and organisation, these are no more than half the story. We must also examine the rebel aims, in so far as these can be inferred from the appeals which they made and the arguments which they used in order to legitimate their rule. These appeals have to be treated with caution; they were the product of a few desperate days in which the rebels' overwhelming need was to gain support, and they do not necessarily show what the new régime would have tried to do if established in power. But they

1 Greenfield, Ethiopia, pp. 379-81 and 398-9. 
show the peculiar mixture of traditional and modernising elements which went into the revolt.

There were during the coup frequent appeals to traditional authority. The rebels used the Crown Prince to read out their initial proclamation which announced 'the new Ethiopian Government formed by me', in order to counterbalance the Emperor's authority, and to reassure waverers by associating the new régime with the accepted and legitimate succession; this is a common theme in palace revolts. By appointing Ras Imru as Prime Minister, the rebels capitalised both on his reputation for honesty and reform and on the fact that he was the Emperor's cousin, a universally known great man, and hence an important member of the hierarchy of high-status individuals who surround the throne. They thus intended to retain the throne and the imperial family-even though Asfa-Wasan was not formally proclaimed as Emperor-and tried to harness the very strong deferential element in Ethiopian society.

Most astonishing of all in the rebel recognition of traditional authorities was the complete absence of any mention of the Emperor Haile Selassie in all their propaganda. They attacked his Government in general terms, but the Emperor himself was so widely revered that they could not attack him without shaking even that support which they already possessed; and in telling the Bodyguard that they were fighting for the Emperor, they even tried to make use of the monarch whose authority they were trying to overthrow. This shows very clearly the kind of political society to which the rebels had to adapt themselves.

However, the main thrust of the rebel appeal for support was directed at the modernising sector. The keynote was struck in the central sentence of their initial proclamation: 'The great strides being taken by the newly independent African states, advancing as they are day by day, have made the people of Ethiopia realise that these new nations are achieving so great a rate of progress that they are leaving Ethiopia far behind in economic development, education, and living standards.'

This emphasis on economic development and the comparison with other African states are both characteristic of Germamé, and the same themes were repeated in later broadcasts. ${ }^{1}$ Yet when we get down to examining the rebel aims, we find that their actual policies and proposals contained very little that was strikingly different from the existing régime. The policy statement which they made was moderate, even rather dull; it reads more like a Labour Party election programme

1 The broadcasts reported in Greenfield's Ethiopia have here been supplemented by my tape-recordings of English and Amharic broadcasts. 
than a revolutionary call to arms. It promised new factories and industries, improved living standards, assistance to farmers and traders, the establishment of new schools and technical colleges, and measures to deal with urban unemployment. It assured foreigners that capital investment in Ethiopia would not be disturbed, provided that it contributed to the country's well-being, and announced the new government's adherence to existing international obligations.

In general, the policy statement seems to have been designed not to give offence to any major interest, and it contained nothing that could not have been (and very little that had not been) said by Haile Selassie. It showed the rebel awareness of the language of development, but the existing régime had used such language too, for example in the first Five-Year-Plan, which started in 1957. The only new proposal in the broadcasts, which appeared in a last desperate bid for support just before the fighting broke out, promised that everyone would be given land and that those whose land had been compulsorily purchased could buy it back again. This reflects the great value placed on land by Ethiopians, and is certainly at variance with the Government's later claim that Germamé wanted all land to be nationalised.

Of course, we do not know how much these policies represented what the rebels actually wanted to do, and how much was due to the pressure of the situation. But at least they indicate, first, that no 'revolutionary' element in the coup can be traced to its specific proposals and, secondly, that the rebels were working in an atmosphere in which radical policies would not have been approved.

The difference between the rebels and the existing Government is largely one of tone. The theme of their attack is the stagnation of the imperial régime rather than, say, its oppression or corruption, and reflects their opposition to the system's concern with maintenance at the expense of development. It may be taken as an insistence that the Government should take an active part in fostering economic development, rather than simply balancing existing pressures in the polity, and most of what is identifiably new in the aims and inspiration of the coup can be traced to this demand.

By contrast with the emphasis on economic development, there is very little appeal to 'liberal' themes, such as constitutional reform, human rights, elections, and the return to civilian rule, which one might expect in the overthrow of a dictatorial régime. Asfa-Wasan announced in the initial broadcast that he would serve under the existing constitution, and there are several generalised references to the new 'government of the people'; but otherwise such themes appear only in 
the rather different statements of the students. The main policy statement announced that parliament, one chamber of which was elected by adult suffrage, would be adjourned sine die. ${ }^{1}$ There is no suggestion that the new régime intended to be any less authoritarian than that which it replaced. For this, the peculiar circumstances of Ethiopia were responsible; Ethiopia has never had to call on 'one man, one vote' as a legitimation for independence, and it has had no reason to place much value on democratic forms of government. By the same token, a military-based régime does not call for that special justification which was found necessary after West African coups d'état.

A final section of the rebel appeal was specifically directed at the armed forces. The suggestion that Bodyguard discontents contributed to the coup is reinforced by an item in the policy statement that 'members of the armed forces will have more clearly defined privileges and personal freedom'; and, shortly before the fighting broke out, a further proclamation was issued which decried the poverty in which soldiers lived and promised a large increase in military pay. This manœuvre was obviously designed to win over the army, but it also showed that the rebels relied on a very narrow support base which they could not afford to offend; they were riding the tiger.

One other possible appeal was ignored: no concessions were made to ethnic particularism or to the regional groupings in the heterogeneous empire. The rebels, like those whom they sought to overthrow, were led by men from the central province of Shoa and did not question the basis of national unity.

\section{LIMITED SOURCES OF SUPPORT}

Whatever the modernising appeals made by the rebels, they failed to generate new sources of support, except for the symbolic adherence of the students. There was in Ethiopia only a very small group of people capable of responding to such appeals, and even within this group the response was at best ambivalent. Most important of all, there was no response among the younger officers of the armed forces, outside the Bodyguard; some air force officers appear to have had doubts about helping to crush the revolt, ${ }^{2}$ but in the event they did so.

The political support available to the loyalists makes an interesting comparison with that of the rebels. Like the latter, they were led by noblemen from Shoa, though by members of a different lineage group, and

1 From a tape-recording in my possession; this was the tenth of the eleven items in the policy statement.

${ }^{2}$ Greenfield, Ethiopia, p. 421 . 
they too could command a section of the armed forces. Where the rebels appealed to Asfa-Wasan as a royal leader, the loyalists invoked Haile Selassie himself. The loyalists in addition called on the Patriarch, and hence on religious legitimacy; the rebels erred tactically in making no reference to God in any of their proclamations.

On the loyalist side, too, only a marginal part was played by new politicians unendowed with traditional authority. Haile Selassie had built up a personal élite of officials, some educated and some not, who owed their advancement to him and could therefore be expected to support him. But in the crisis they could do virtually nothing, having no inherent authority, and no power base on which they could call; this is another point at which the absence of any political organisation made itself felt. Some of them equivocated with the rebels; some fled from Addis Ababa; some attached themselves to the army; but none of them had any effect on the result.

The dilemma of this group is summed up in the position of the Minister of Commerce, Makonnen Habta-Wald. Makonnen was a devious and intriguing politician from a humble family, unshakably loyal to the Emperor, who ran an intelligence network on Haile Selassie's behalf. He had inklings of what was up before the coup broke out, but with the Emperor out of the country there was practically nothing he could do. The police, security, and Bodyguard chiefs were all in the plot. The army leaders and noblemen despised Makonnen as a lower-class upstart; they neither trusted nor were trusted by him. Makonnen himself had not the authority to give orders directly to the police or the military, as a high nobleman could have done. So he was reduced to sending frantic telegrams to the Emperor, far away in Brazil, until the coup took place and he was captured and shot.

When it came to a crisis, therefore, the effective sources of authority on both sides went straight back to the long-standing foundations of the Ethiopian state. Though the armed forces were better organised than before, virtually no new element was involved which had not already been present 50 , I00, or 400 years before. We can illustrate this by a comparison with the I 9 I 6 coup d'etat, in which the Emperor Lej Iyasu was overthrown and Haile Selassie (Tafari as he was then called) became Regent. Here again the Emperor was away from Addis Ababa, and the effective actors were the Shoan noblemen and military leaders in the capital, the forces which they commanded, the members of the imperial family on whom they could call as an alternative source of legitimacy (in this case the Emperor's aunt and cousin), and the head of the Church. The difference between the two coups is that in 1916 the 
head of the Church, the Shoan noblemen, and the army commanders were united in revolt, whereas in 1960 the head of the Church was with the loyalists, and the nobility and armed forces were divided. An analogous combination of forces, to go still further back, had accounted for the deposition of the Emperor Susenyos in $163^{2}$.

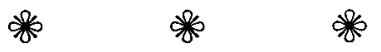

Any conclusions must take account of the fact that a great deal about the I96o coup d'état remains unknown or hypothetical. We have no means of telling what its leaders would have tried to do, for they had no chance to prove themselves. It is still possible to claim that they would have tried to bring about really fundamental political changes. But, on the available contemporary evidence, this would-be reformist revolt was not radically different in policy from the existing government, though in practice far more strongly committed to economic development and the need for the government to take an active part in achieving it. In resorting to a palace putsch, it took the only available means for pressing these views in a system which excluded any peaceful change of government.

It also marked a new willingness to challenge the régime violently on modernising grounds. Any violent assault on a Government established for as long as Haile Selassie's is in itself remarkable, and if it is directed towards progressive ideals it may automatically be hailed as the millennium without much consideration of what it is actually about. There was something of this in the attitude of the university students; and subsequent underground reformist propaganda has similarly tended to idealise the coup; the one positive advantage of failure, after all, is to permit the formulation of myths which could not long have survived success.

The rebels themselves gave little guidance on the form which they intended their future régime to take; their own ideas may very well have been unclear. But, whatever their intentions, they were bound, willy-nilly, by the political traditions and conventions of the society in which the coup took place. In this respect, it does not matter whether they thought that the Emperor was beyond criticism or that the throne should be retained; the important fact is that they were constrained by the conditions under which they were operating from taking the obvious line on these matters which might have been expected. Even had they solved the immediate military problem, they would still have had to come to terms with a social and political structure in which a 'revolution' was impossible. 
THE ETHIOPIAN COUP D'ETAT OF DEGEMBER I960 507

In reaching this conclusion, I do not wish either to discount the myths which have grown around the coup or to suggest that fundamental changes are not possible in the future. The revolt may yet prove more potent in legend than in fact, though the political ferment which followed it in early $196 \mathrm{r}$ has long since faded away. And the Ethiopian polity is likely to change as increased political mobilisation both raises the level of demands and reduces the ability of existing power structures to deal with them. The eight years since the coup have been uneventful -and help to show that this was no case of urgent and irrepressible pressures blowing the lid off the political system-but political awareness in Ethiopia has grown considerably, in large measure as a result of the coup itself. New movements may call on discontents among the peasantry of which the 1960 rebels were aware, but with which they failed to establish any contact, and also on ethnic and regional divisions which they did not recognise. Though traditional authorities were enough to contain and defeat the I96o coup d'état, therefore, there is no assurance that they will continue to be similarly successful. 